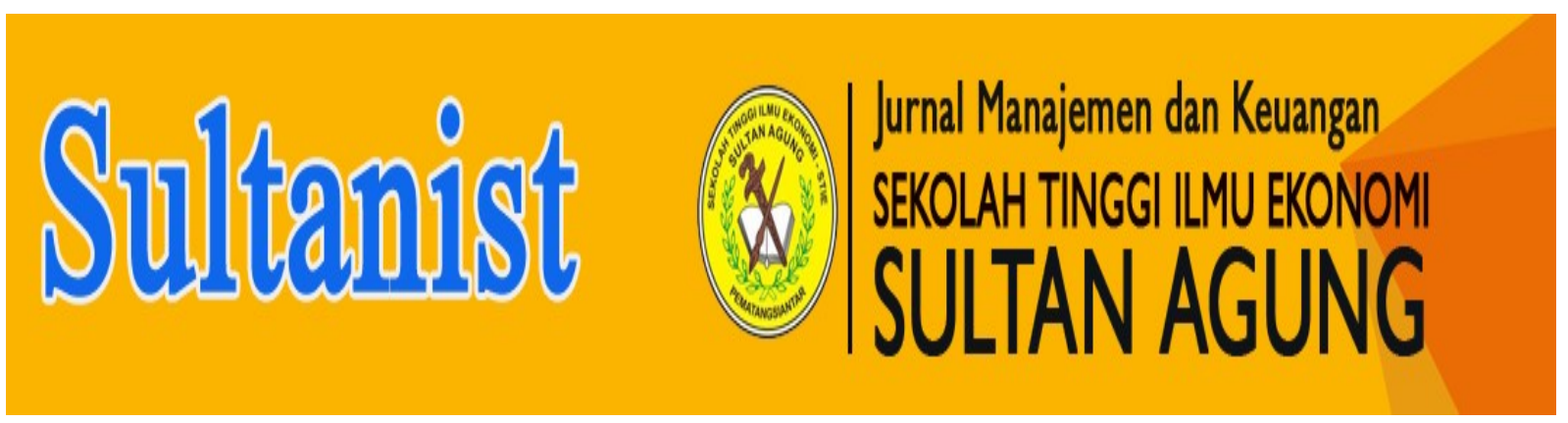

\title{
EFEKTIVITAS PENGELOLAAN ALOKASI DANA DESA DALAM MENINGKATKAN PEMBANGUNAN FISIK DESA KARANG SARI KECAMATAN GUNUNG MALIGAS KABUPATEN SIMALUNGUN
}

\author{
Oleh : \\ Noni Prihana \\ S1 Akuntansi \\ Dr. Yansen Siahaan, Ady Inrawan, Christine Dewi Nainggolan
}

Abstrak

Tujuan penelitian ini adalah: 1. Untuk mengetahui gambaran umum pengelolaan Alokasi Dana Desa dalam pembangunan fisik Desa Karang Sari Kecamatan Gunung Maligas Kabupaten Simalungun. 2. Untuk mengetahui efektivitas pengelolaan Alokasi Dana Desa dalam pembangunan fisik Desa Karang Sari Kecamatan Gunung Maligas Kabupaten Simalungun.

Penelitian ini menggunakan penelitian lapangan dan penelitian kepustakaan. Pengumpulan data pada penelitian ini adalah kuisioner dan dokumentasi. Responden dalam penelitian ini adalah beberapa Badan Permusyawaratan Desa dan masyarakat desa yang memahami alokasi dana desa pada Desa Karang Sari Kecamatan Gunung Maligas Kabupaten Simalungun. Teknik analisis yang digunakan adalah analisis deskriptif kualitatif dan analisis induktif.

Hasil penelitian ini dapat disimpulkan bahwa pembangunan fisik Desa Karang Sari Kecamatan Gunung Maligas Kabupaten Simalungun sudah dikatakan efektif. Pembangunan fisik Desa Karang Sari telah dilakukan berdasarkan kesepakatan dan musyawarah bersama. Serta, Pengelolaan alokasi dana desa telah berdasarkan prinsip perencanaan, pelaksanaan dan pengawasan.

Adapun saran dari hasil penelitian ini adalah Pemerintah Desa Karang Sari perlu mengembangkan beberapa pembangunan ditahun yang akan datang dan melakukan sosialisasi mengenai alokasi dana desa kepada semua lapisan masyarakat Desa Karang Sari Kecamatan Gunung Maligas Kabupaten simalungun.

Kata Kunci: Alokasi Dana Desa, Pembangunan Fisik

\section{Abstract}

The objectives of this research are: 1. To find out the general description of the Village Fund Allocation management in the physical development of Karang Sari Village, Gunung Maligas District, Simalungun Regency. 2. To determine the effectiveness of the management of Village Fund Allocation in the physical development of Karang Sari Village, Gunung Maligas District, Simalungun Regency.

This research uses field research and library research. Data collection in this research were questionnaires and documentation. Respondents in this research were several Village Consultative Bodies and village communities who understood the allocation of village funds in Karang Sari Village, Gunung Maligas District, Simalungun Regency. The analysis technique used is qualitative descriptive analysis and inductive analysis.

The results of this research can be concluded that the physical development of Karang Sari Village, Gunung Maligas District, Simalungun District has been said to be effective. The physical development of Karang Sari Village has been carried out based on mutual agreement and deliberation. As well, Management of village fund allocation has been based on the principles of planning, implementation and supervision.

The suggestion of the results of this research that the Karang Sari Village Government needs to develop some future development and socialize the allocation of village funds to all levels of society in Karang Sari Village, Gunung Maligas District, Simalungun Regency.

Keywords: Village Fund Allocation, Physical Development

\section{PENDAHULUAN}

\section{a. Latar Belakang Masalah}

Pembangunan Desa merupakan pembangunan yang dibuat dengan tujuan untuk meningkatkan kesejahteraan masyarakat desa dan kualitas hidup yang lebih baik. Jenis pembangunan itu sendiri terbagi menjadi dua yaitu pembangunan fisik dan pembangunan non fisik. Pembangunan fisik merupakan pembangunan yang dapat dirasakan dan terlihat oleh mata sementara pembangunan non fisik merupakan pembangunan yang berkaitan dengan sumber daya manusia. Pembangunan harus dilakukan secara efektif dan efisien sebab melalui pembangunan potensi yang ada dipedesaan dapat

SULTANIST: Jurnal Manajemen dan Keuangan ISSN : 2338-4328 Vol. 6, No. 2, Desember 201824 
dikembangkan dan kekurangan yang ada dapat teratasi. Untuk meningkatkan pembangunan yang lebih baik dibutuhkan pendanaan yang lebih yaitu Alokasi Dana Desa (ADD).

Berdasarkan hasil wawancara dengan pihak nagori maka diperoleh informasi sebagai berikut:

Tabel 1.1

Persentase Pembangunan Fisik Desa Karang Sari tahun 2017

\begin{tabular}{|c|l|c|}
\hline No & \multicolumn{1}{|c|}{$\begin{array}{c}\text { Perencanaan } \\
\text { Pembangunan } \\
\text { Fisik }\end{array}$} & Persentase \\
\hline 1 & Perkerasan lapen & $34.70 \%$ \\
\hline 2 & Perkerasan Telford & $26.41 \%$ \\
\hline 3 & Perkerasan Rabat Beton & $13.79 \%$ \\
\hline 4 & $\begin{array}{l}\text { Parit Pasangan dan Plat } \\
\text { Beton }\end{array}$ & $5.07 \%$ \\
\hline \multicolumn{2}{|c|}{ Persentase Keseluruhan } & $79.97 \%$ \\
\hline
\end{tabular}

Sumber: Hasil Wawancara tahun 2018

Berdasarkan tabel 1.1 tersebut dapat diketahui bahwa perencanaan pembangunan desa sudah sangat efektif. Akan tetapi, berdasarkan total persentase perencanaan pembangunan hasil wawancara mencapai 79.97\%. Berdasarkan Peraturan Pemerintah No.47 tahun 2015 pasal 100 bahwa penggunaan dana desa paling sedikit $70 \%$ membiayai pelaksanaan pembangunan Desa, penyelenggaraan Pemerintah Desa, pembinaan kemasyarakatan Desa serta pemberdayaan masyarakat Desa dan $30 \%$ untuk biaya operasional, penghasilan tetap dan tunjangan kepala Desa, perangkat Desa, Tunjangan Badan Permusyawaratan Desa, Rukun Tetangga dan Rukun Warga.

\section{b. Rumusan Masalah}

Berdasarkan latar belakang masalah yang dijelaskan sebelumnya, maka rumusan masalah dalam penelitian ini adalah:

a. Bagaimana gambaran umum pengelolaan Alokasi Dana Desa dalam pembangunan fisik Desa Karang Sari Kecamatan Gunung Maligas Kabupaten Simalungun?

b. Bagaimana efektivitas Pengelolaam Alokasi Dana Desa dalam pembangunan fisik Desa Karang Sari Kecamatan Gunung Maligas Kabupaten Simalungun?

\section{c. Tujuan Penelitian}

Adapun tujuan penelitian ini adalah:

a. Untuk mengetahui gambaran umum pengelolaan Alokasi Dana Desa dalam pembangunan fisik Desa Karang Sari Kecamatan Gunung Maligas Kabupaten Simalungun

b. Untuk mengetahui efektivitas Pengelolaam Alokasi Dana Desa dalam pembangunan fisik Desa Karang Sari Kecamatan Gunung Maligas Kabupaten Simalungun

\section{d. Metodologi Penelitian}

Penelitian ini menggunakan data primer yaitu dengan mencari data-data di Kantor Lurah Karang Sari Kecamatan Gunung Maligas Kabupaten Simalungun dan fakta-fakta lapangan yang terjadi di Desa Karang Sari Kecamatan Gunung Maligas Kabupaten Simalungun. Desain penelitian ini adalah penelitian lapangan (field research) dan penelitian kepustakaan (library research). Teknik analisa data yang digunakan adalah metode deskriptif kualitatif dan metode induktif.

\section{LANDASAN TEORI}

\section{a. Akuntansi Sektor Publik}

Menurut Mardiasmo (2002:14), akuntansi sektor publik adalah: "alat informasi baik bagi pemerintah sebagai manajemen maupun alat informasi bagi publik". Selanjutnya, menurut Renyowijoyo (2008:25), akuntansi sektor publik adalah: "sistem akuntansi yang dipakai oleh lembaga-lembaga publik sebagai salah satu alat pertanggungjawaban kepada publik". Akuntansi pemerintahan sebagai alat informasi dan alat pertanggungjawaban pemerintah kepada publik

Menurut Nordiawan, Iswahyudi dan Maulidah (2008:4), Akuntansi sektor publik adalah: "memberikan informasi keuangan dari entitas-entitas yang tidak mencari laba". Akuntansi sektor publik memberikan informasi keuangan dalam pengambilan keputusan dan tidak mencari laba.

\section{b. Tujuan Akuntansi Sektor Publik}

Akuntansi sektor publik memiliki beberapa tujuan yang dapat membantu pihak berkepentingan dalam pengambilan keputusan. Menurut Bastian (2006:96), laporan keuangan akuntansi sektor publik memiliki beberapa tujuan yaitu: Menyediakan informasi mengenai sumber-sumber, alokasi, dan penggunaan sumber daya finansial, Menyediakan informasi mengenai bagaimana entitas mendanai aktivitasnya dan memenuhi persyaratan kasnya, Menyediakan informasi yang berguna dalam mengevaluasi kemampuan entitas untuk mendanai aktivitasnya dan memenuhi kewajiban serta komitmennya, Menyediakan informasi mengenai kondisi keuangan suatu entitas dan perubahan didalamnya, Menyediakan informasi menyeluruh dan mengevaluasi kinerja entitas atas hal biaya jasa, efisiensi dan pencapaian tujuan.

\section{c. Dana Desa}

Berdasarkan Permendagri No.114 Pasal 1 bahwa dana desa adalah dana yang bersumber dari anggaran pendapatan dan belanja negara yang diperuntukkan bagi desa yang ditransfer melalui Anggaran Pendapatan 
dan Belanja Daerah (APBD) kabupaten maupun kota serta digunakan untuk membiayai penyelenggaraan Pemerintah Desa, pelaksanaan pembangunan desa, pembinanaan kemasyarakatan desa, dan pemberdayaan masyarakat desa. Selanjutnya, menurut Mulyani (2017:7) bahwa dana desa adalah "dana APBN yang diperuntukkan bagi desa dan ditransfer melalui APBD kabupaten/kota dan diprioritaskan untuk pelaksanaan pembangunan dan pemberdayaan masyarakat desa. dana desa adalah dana yang bersumber dari APBN yang dapat digunakan untuk membiayai setiap pelaksanaan Desa.

\section{d. Efektivitas}

Pengelolaan suatu organisasi harus dilaksanakan sebaik mungkin agar tujuan utama suatu organisasi dapat tercapai dengan maksimal dan efektif. Menurut Mardiasmo (2002:134), efektivitas adalah: "ukuran berhasil tidaknya suatu organisasi berhasil mencapai tujuan, maka organisasi tersebut berjalan dengan efektif". Efektif dapat mengukur berhasil atau tidaknya suatu organisasi. Menurut Bastian (2006:280), efektivitas adalah :"hubungan antara output dan tujuan. Dimana efektivitas diukur berdasarkan tingkat output, kebijakan dan prosedur organisasi mencapai tujuan yang telah ditetapkan. Efektivitas digunakan sebagai ukuran dan kemampuan suatu organisasi mencapai tujuan. Menurut Bastian (2006:78), bahwa efektivitas sesungguhnya adalah: "kesuksesan atau kegagalan dalam mencapai tujuan. efektivitas adalah ukuran keberhasilan suatu organisasi untuk mencapai tujuan dengan rencana yang telah ditetapkan.

\section{e. Alokasi Dana Desa}

Berdasarkan Permendagri No.114 tahun 2014 pasal 1 bahwa Alokasi Dana Desa adalah "dana perimbangan yang diterima kabupaten/kota dalam Anggaran Pendapatan dan Belanja Daerah (APBD) kabupaten/kota setelah dikurangi Dana Alokasi Khusus (DAK)". Selanjutnya menurut Santoso (2008:339), Alokasi Dana Desa dimaksudkan untuk: "membiayai program pemerintah desa dalam melaksanakan kegiatan Pemerintah Desa dan Pemberdayaan Masyarakat". Alokasi Dana Desa yaitu dana perimbangan yang diterima untuk membiaya program pada daerah Pemerintah Desa.

Menurut Kurnia (2015:49), alokasi dana desa adalah "bagian dari dana perimbangan yang diterima oleh pemerintah daerah dari Kabupaten/Kota paling sedikit 10\% setelah dikurangi Dana Alokasi Khusus (DAK).

Dari beberapa definisi tersebut maka dapat disimpulkan bahwa Alokasi Dana Desa adalah dana dari APBD Kabupaten/Kota yang bersumber dari dana perimbangan keuangan pusat dan daerah yang diterima oleh Pemerintah/Kabupaten untuk desa paling sedikit $10 \%$ yang digunakan untuk membiayai program Pemerintah Desa.

\section{f. Pembangunan Fisik}

Menurut Deddy dan Supriadi bahwa pembangunan adalah proses perubahan yang dilakukan melalui upaya-upaya secara sadar dan terencana. Selanjutnya, menurut Kuncuro (2010:20), pembangunan fisik adalah: "pembangunan yang dapat dirasakan langsung oleh masyarakat atau pembangunan yang tampak oleh mata". Pembangunan diperlukan dalam suatu desa untuk meningkatkan kualitas hidup masyarakat yang lebih baik. Selanjutnya, menurut Undang-undang (UU) No.6 tahun 2014 pembangunan desa adalah "upaya peningkatan kualitas hidup dan kehidupan untuk sebesar-besarnya kesejahteraan masyarakat desa.

\section{g. Hubungan Alokasi Dana Desa} dengan Pembangunan Fisik Desa

Pembangunan fisik desa harus memperhatikan kondisi desa. Berdasarkan Permendes No.5 tahun 2015 bahwa prioritas penggunaan dana desa dialokasikan untuk pembangunan Desa yaitu dengan tujuan untuk meningkatkan kesejahteraan masyarakat Desa dan kualitas hidup manusia serta penanggulangan kemiskinan, melalui: pemenuhan kebutuhan dasar, pembangunan sarana dan prasarana Desa, pengembangan potensi ekonomi local, Pemanfaatan sumber daya alam dan lingkungan secara berkelanjutan.

\section{PEMBAHASAN}

a. Analisis

\section{i. Analisis Deskripsi Kualitatif}

Penetapan kriteria nilai rata-rata jawaban dari responden tersebut dimasukkan ke dalam kelas-kelas interval dimana penentuan intervalnya menggunakan rumus sebagai berikut:

Nilai Tertinggi - Nilai Terendah Sugiyono 2013:172

Kriteria:

1. Nilai tertinggi adalah $=5$

2. Nilai terendah adalah $=1$

3. Jumlah kelas adalah $=5$

Dari rumus tersebut maka dapat diperoleh interval kelas 0.8 sehingga berlaku ketentuan kategori dengan hasil sebagai berikut:

Tabel 5.1 
Nilai Interval dan Kategori Jawaban Responden

\begin{tabular}{|c|c|c|}
\hline \multirow{2}{*}{ Nilai Interval } & \multicolumn{2}{|c|}{ Kategori } \\
\cline { 2 - 3 } & $\begin{array}{c}\text { Alokasi Dana } \\
\text { Desa }\end{array}$ & $\begin{array}{c}\text { Pembangunan } \\
\text { Fisik }\end{array}$ \\
\hline $1,00-1,80$ & Sangat Tidak Setuju & Sangat Tidak Efektif \\
\hline $1,81-2,80$ & Tidak Setuju & Tidak Efektif \\
\hline $2,61-3,40$ & Cukup Setuju & Cukup efektif \\
\hline $3,41-4,20$ & Setuju & Efektif \\
\hline $4,21-5.00$ & Sangat Setuju & Sangat Efektif \\
\hline
\end{tabular}

\section{Sumber: Pengolahan Data}

\section{Gambaran Alokasi Dana Desa}

Berikut ini ditampilkan tabel atas responden mengenai alokasi Belanja Dana Desa pada Desa Karang Sari Kecamatan Gunung Maligas Kabupaten Simalungun sebagai berikut:

Tabel 5.2

Rekapitulasi Jawaban Responden Mengenai Belanja Desa

\begin{tabular}{|c|c|c|c|c|c|c|c|c|}
\hline \multirow{2}{*}{ No } & \multirow{2}{*}{$\begin{array}{c}\text { Belanja Dana } \\
\text { Desa }\end{array}$} & \multicolumn{5}{|c|}{ Jawaban } & \multirow{2}{*}{$\begin{array}{l}\text { Nilai } \\
\text { rata- } \\
\text { rata }\end{array}$} & \multirow{2}{*}{$\begin{array}{l}\text { Kriteria } \\
\text { Jawaban }\end{array}$} \\
\hline & & ss & $S$ & KS & TS & STS & & \\
\hline 1 & $\begin{array}{l}\text { Dana Desa } \\
\text { merupakan } \\
\text { dana } \\
\text { perimbangan } \\
\text { yang } \\
\text { diberikan } \\
\text { kepada } \\
\text { Desa dengan } \\
\text { tujuan } \\
\text { untuk } \\
\text { pembangunan } \\
\text { Desa }\end{array}$ & 3 & 13 & 4 & 0 & 0 & 3,95 & Setuju \\
\hline
\end{tabular}

Tabel 5.2 (lanjutan)

Rekapitulasi Jawaban Responden

Mengenai Belanja Desa

\begin{tabular}{|c|l|l|l|l|l|l|l|l|}
\hline \multirow{2}{*}{ No } & $\begin{array}{l}\text { Belanja } \\
\text { Dana Desa }\end{array}$ & SS & S & KS & TS & STS & rata-rata & Jawaban \\
\cline { 3 - 7 } 2 & $\begin{array}{l}\text { Alokasi Dana } \\
\text { Desa } \\
\text { dapat } \\
\text { membantu } \\
\text { masyarakat } \\
\text { desa terkait } \\
\text { pembangunan } \\
\text { fisik desa }\end{array}$ & 5 & 15 & 0 & 0 & 0 & 4,25 & $\begin{array}{l}\text { Sangat } \\
\text { Setuju }\end{array}$ \\
\hline 3 & $\begin{array}{l}\text { Pembangunan } \\
\text { fisik } \\
\text { desa dapat } \\
\text { meningkatkan } \\
\text { kesejahteraan } \\
\text { masyarakat } \\
\text { desa }\end{array}$ & 7 & 12 & 1 & 0 & 0 & 4,30 & $\begin{array}{l}\text { Sangat } \\
\text { Setuju }\end{array}$ \\
\hline $\begin{array}{l}\text { Alokasi Dana } \\
\text { Desa } \\
\text { digunakan } \\
\text { untuk } \\
\text { mengembang } \\
\text {-kan } \\
\text { pos } \\
\text { kesehatan } \\
\text { desa, } \\
\text { polindes dan } \\
\text { posyandu }\end{array}$ & 4 & 9 & 7 & 0 & 0 & 3,85 & Setuju \\
\hline 5 & $\begin{array}{l}\text { Alokasi Dana } \\
\text { Desa untuk }\end{array}$ & 4 & 14 & 2 & 0 & 0 & 4,10 & Setuju \\
\hline
\end{tabular}

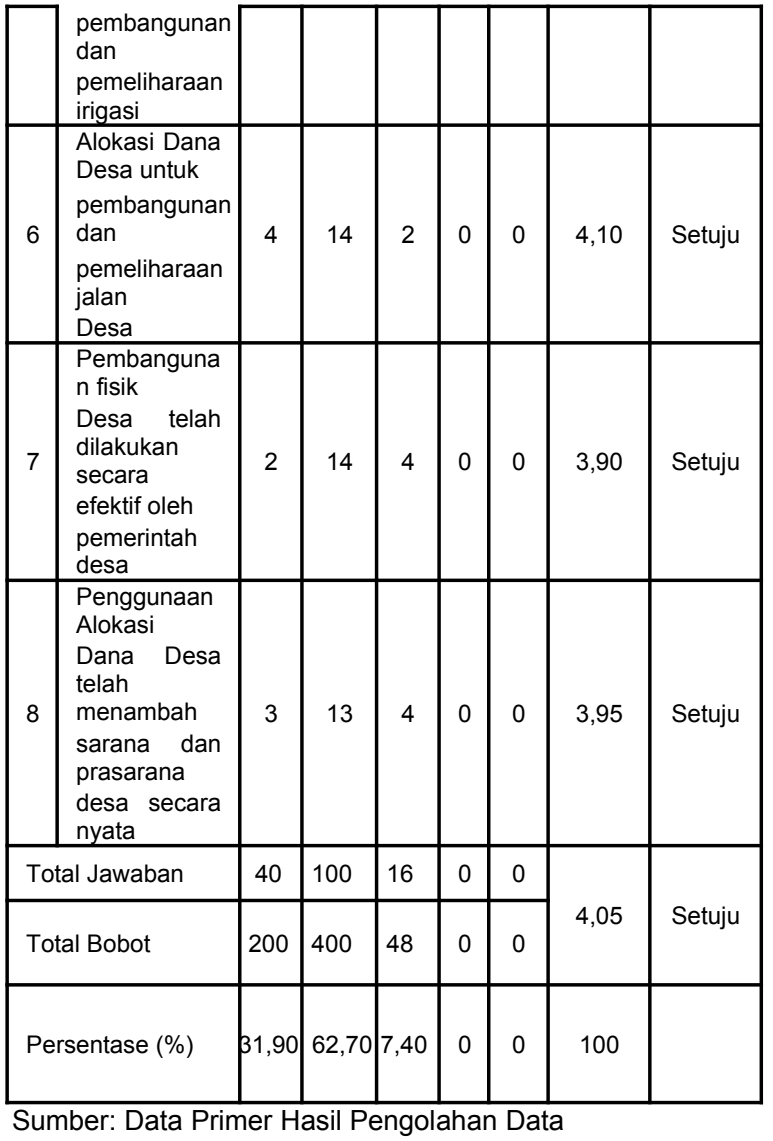

Dari tabel 5.2 Secara keseluruhan dapat dilihat bahwa nilai rata-rata belanja dana desa berada pada rata-rata 4,05 dan dalam kategori setuju. Selanjutnya nilai tertinggi dari belanja desa 4,30 dalam kategori sangat setuju yaitu pembangunan dapat meningkatkan kesejahteraan. Serta nilai terendah dalam belanja dana desa adalah 3,85 dalam kategori setuju yaitu pengembangan pos kesehatan, polindes dan posyandu.

\section{Gambaran Pembangunan Fisik}

1) Perencanaan

Berikut data mengenai perencanaan pembangunan fisik Desa Karang Sari Kecamatan Gunung Maligas Kabupaten Simalungun.

Tabel 5.3

Rekapitulasi Jawaban Responden Mengenai

\begin{tabular}{|c|c|c|c|c|c|c|c|c|}
\hline \multirow[b]{3}{*}{ No } & & & & & & & & \\
\hline & \multirow[b]{2}{*}{ Perencanaan } & \multicolumn{5}{|c|}{ Jawaban } & \multirow{2}{*}{$\begin{array}{l}\text { Nilai } \\
\text { Rata- } \\
\text { rata }\end{array}$} & \multirow{2}{*}{$\begin{array}{l}\text { Kriteria } \\
\text { Jawaban }\end{array}$} \\
\hline & & SE & $\mathrm{E}$ & CE & TE & STE & & \\
\hline 1 & $\begin{array}{l}\text { Pemerintah } \\
\text { desa } \\
\text { menyusun } \\
\text { rencana } \\
\text { pembangunan } \\
\text { jangka } \\
\text { menengah } \\
\text { (RPJMDes) } \\
\end{array}$ & 2 & 17 & 1 & 0 & & 4 & Efektif \\
\hline 2 & $\begin{array}{l}\text { Pemerintah } \\
\text { desa telah }\end{array}$ & 3 & 17 & 0 & 0 & & 4 & Efektif \\
\hline
\end{tabular}




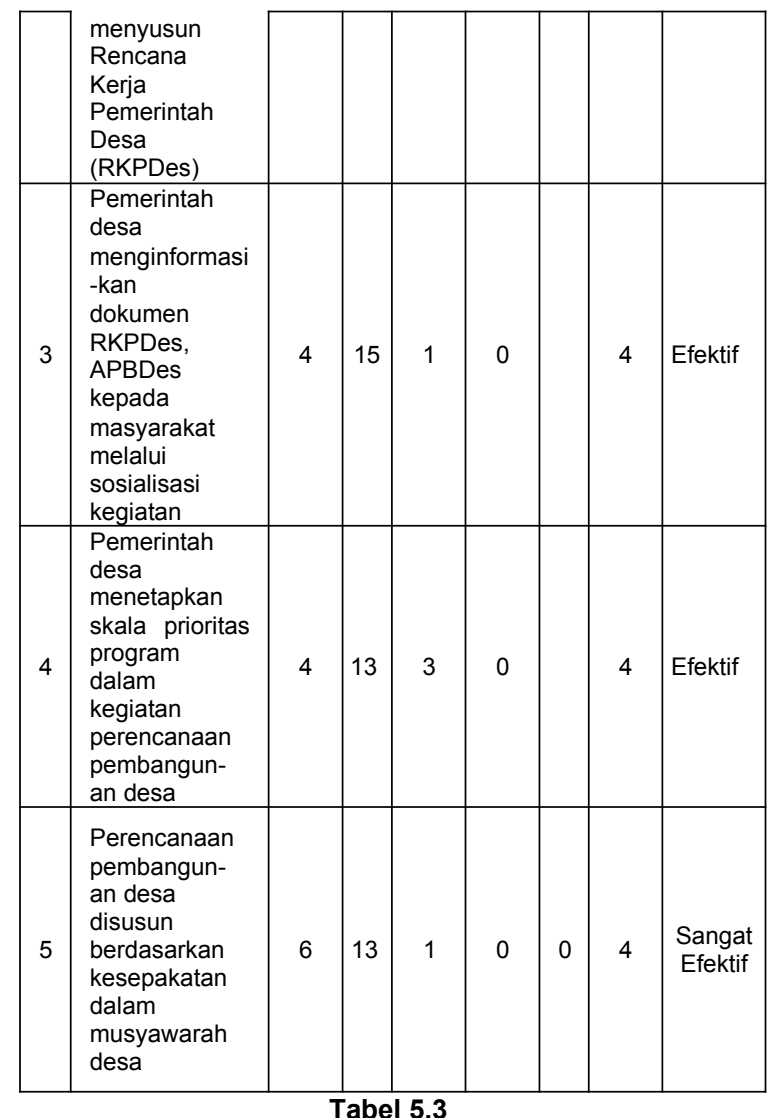

Rekapitulasi Jawaban Responden Mengenai

\begin{tabular}{|c|c|c|c|c|c|c|c|c|}
\hline \multirow{3}{*}{ No } & \multicolumn{8}{|c|}{ Perencanaan } \\
\hline & \multirow{2}{*}{ Perencanaan } & \multicolumn{5}{|c|}{ Jawaban } & \multirow{2}{*}{$\begin{array}{c}\text { Nilai } \\
\text { rata-rata }\end{array}$} & \multirow{2}{*}{$\begin{array}{l}\text { Kriteria } \\
\text { Jawaban }\end{array}$} \\
\hline & & SE & $\bar{E}$ & $\mathrm{CE}$ & TE & STE & & \\
\hline 6 & $\begin{array}{l}\text { Pemerintah } \\
\text { Desa } \\
\text { melibatkan } \\
\text { masyarakat } \\
\text { dalam } \\
\text { penyusunan } \\
\text { Rencana } \\
\text { Kerja } \\
\text { Pemerintah } \\
\text { Desa } \\
\text { (RKPDes) }\end{array}$ & 5 & 14 & 1 & 0 & & 4 & Efektif \\
\hline \multicolumn{2}{|c|}{ Total Jawaban } & 24 & 89 & 7 & 0 & & \multirow[t]{2}{*}{4} & \multirow{2}{*}{ Efektif } \\
\hline & Total Bobot & 120 & 356 & 21 & 0 & & & \\
\hline \multicolumn{2}{|c|}{ Persentase (\%) } & 24 & 72 & 4 & 0 & & 100 & \\
\hline
\end{tabular}

Sumber: Data Primer Hasil Pengolahan

Dari tabel 5.3 tersebut maka dapat dijelaskan bahwa rekapitulasi jawaban responden mengenai perencanaan pembangunan secara keseluruhan yaitu berada pada rata-rata 4,14 dan dalam kategori efektif. Nilai tertinggi dari perencanaan 4,25 yaitu perencanaan pembangunan dilakukan dengan musyawarah dalam kategori sangat efektif serta nilai terendah 4,05 yaitu penyusunan Rencana Kerja Jangka Menengah Desa (RPJMDes) dan penetapan skala prioritas dalam kategori efektif.

\section{2) Pelaksanaan}

Berikut tabel rekapitulasi jawaban responden mengenai pelaksanaan.

Tabel 5.4

Rekapitulasi Jawaban Responden Mengenai Pelaksanaan

\begin{tabular}{|c|c|c|c|c|c|c|c|c|}
\hline \multirow{2}{*}{ No } & \multirow{2}{*}{ Pelaksanaan } & \multicolumn{5}{|c|}{ Jawaban } & \multirow{2}{*}{$\begin{array}{c}\text { Nilai } \\
\text { ata-rata }\end{array}$} & \multirow{2}{*}{$\begin{array}{c}\text { Kriteria } \\
\text { Jawab } \\
\text { an }\end{array}$} \\
\hline & & SE & $\mathrm{E}$ & CE & TE & STE & & \\
\hline 1 & $\begin{array}{l}\text { Pemerintah } \\
\text { Desa } \\
\text { menyusun } \\
\text { RPJM } \\
\text { Desa dan } \\
\text { RKPDesa } \\
\end{array}$ & 2 & 17 & 1 & 0 & 0 & 4 & Efektif \\
\hline 2 & $\begin{array}{l}\text { Pemerintah } \\
\text { Melakukan } \\
\text { Pengaduan } \\
\text { Masyarakat } \\
\text { terkait } \\
\text { pembangunar } \\
\text { Desa }\end{array}$ & 3 & 16 & 1 & 0 & 0 & 4 & Efektif \\
\hline 3 & \begin{tabular}{l|} 
Pemerintah \\
Desa \\
menyiapkan \\
informasi \\
terkait \\
pelaksanaan
\end{tabular} & 4 & 15 & 1 & 0 & 0 & 4 & Efektif \\
\hline
\end{tabular}




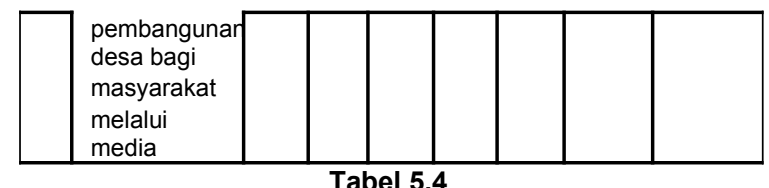

Rekapitulasi Jawaban Responden Mengenai

\begin{tabular}{|c|c|c|c|c|c|c|c|c|}
\hline \multirow{2}{*}{ No } & \multirow{2}{*}{ Pelaksanaan } & \multicolumn{5}{|c|}{ Jawaban } & \multirow{2}{*}{$\begin{array}{l}\text { Nilai } \\
\text { rata- } \\
\text { rata }\end{array}$} & \multirow{2}{*}{$\begin{array}{l}\text { Kriteria } \\
\text { Jawaban }\end{array}$} \\
\hline & & SE & $E$ & $\mathrm{CE}$ & TE & STE & & \\
\hline 4 & $\begin{array}{l}\text { Pemerintah } \\
\text { Desa } \\
\text { menggunakan } \\
\text { Alokasi } \\
\text { Dana Desa } \\
\text { untuk } \\
\text { pembangunan } \\
\text { sarana dan } \\
\text { prasarana } \\
\text { dengan } \\
\text { menggunakan } \\
\text { SDM Lokal } \\
\text { (SWAKELOLA) }\end{array}$ & 4 & 13 & 3 & 0 & 0 & 4 & Efektif \\
\hline 5 & $\begin{array}{l}\text { Pemerintah } \\
\text { Desa } \\
\text { membentuk } \\
\text { kelompok } \\
\text { dalam rangaka } \\
\text { pelestarian } \\
\text { dan menjaga } \\
\text { hasil kegiatan } \\
\text { pembangun-an } \\
\text { desa }\end{array}$ & 1 & 5 & $\begin{array}{l}1 \\
4\end{array}$ & 0 & 0 & 3 & $\begin{array}{l}\text { Cukup } \\
\text { Efektif }\end{array}$ \\
\hline \multicolumn{2}{|r|}{ Total Jawaban } & 14 & 66 & 20 & 0 & 0 & \multirow{2}{*}{4} & \multirow{2}{*}{ Efektif } \\
\hline & Total Bobot & 70 & 264 & 60 & 0 & 0 & & \\
\hline \multicolumn{2}{|r|}{ Persentase (\%) } & 17,76 & 67 & 15,24 & 0 & 0 & 100 & \\
\hline
\end{tabular}

Sumber: Data Primer Hasil Pengolahan

Dari tabel 5.4 yaitu rekapitulasi jawaban responden mengenai pelaksanaan maka dapat dijelaskan bahwa pemerintah desa secara keseluruhan yaitu pelaksanaan pembangunan Desa Karang Sari memperoleh nilai rata-rata 3,94 dan dalam kategori efektif. Nilai tertinggi 4,15 yaitu penyiapan media informasi terkait pembangunan dan nilai terendah 3,35 yaitu pembentukan kelompok untuk menjaga hasil pembangunan.

\section{3) Pengawasan}

Berikut rekapitulasi jawaban responden mengenai pengawasan.

Tabel 5.5

Rekapitulasi Jawaban Responden Mengenai Pengawasan

\begin{tabular}{|c|c|c|c|c|c|c|c|c|}
\hline \multicolumn{9}{|c|}{ Pengawasan } \\
\hline \multirow{2}{*}{ No } & \multirow{2}{*}{ Pengawasan } & \multicolumn{5}{|c|}{ Jawaban } & \multirow{2}{*}{$\begin{array}{c}\text { Nilai } \\
\text { ata-rata }\end{array}$} & \multirow{2}{*}{$\begin{array}{r}\text { Kriteria } \\
\text { Jawaban }\end{array}$} \\
\hline & & SE & $\mathrm{E}$ & $\mathrm{CE}$ & $\mathrm{TE}$ & STE & & \\
\hline 1 & $\begin{array}{l}\text { Pemerintah } \\
\text { desa } \\
\text { melakukan } \\
\text { pemantauan } \\
\text { secara } \\
\text { berkala } \\
\text { terkait } \\
\text { pembangunan } \\
\text { fisik desa }\end{array}$ & 6 & 14 & 0 & 0 & 0 & & $\begin{array}{l}\text { Sangat } \\
\text { Efektif }\end{array}$ \\
\hline
\end{tabular}

Tabel 5.5

Rekapitulasi Jawaban Responden Mengenai Pengawasan

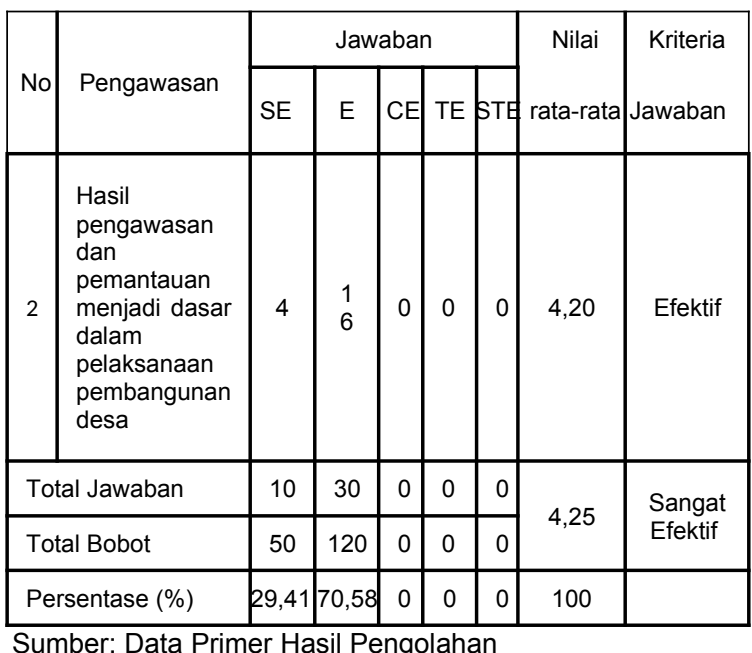

Dari tabel 5.5 tersebut maka dapat dijelaskan bahwa jawaban responden mengenai pengawasan secara keseluruhan yaitu pengawasan Alokasi Dana Desa memperoleh nilai rata-rata 4,25 dan dalam kategori sangat efektif. Nilai tertinggi 4,30 dalam kategori sangat efektif yaitu pemantauan pembangunan dan nilai terendah 4,20 dalam kategori efektif yaitu pembangunan berdasarkan pengawasan.

\subsection{Evaluasi}

\subsubsection{Evaluasi Alokasi Dana Desa}

Dari rekapitulasi jawaban responden mengenai belanja desa pada Desa Karang Sari Kecamatan Gunung Maligas Kabupaten Simalungun sudah dalam kategori setuju. Akan tetapi, masih terdapat beberapa jawaban responden berada dibawah rata-rata 4,05 Indikator jawaban responden yang berada dibawah rata-rata 4,05 yaitu alokasi dana desa digunakan untuk mengembangkan pos kesehatan, polindes, dan posyandu dengan nilai rata-rata 3,85 . Meskipun dalam kategori setuju, akan tetapi pemerintah desa belum merealisasikan dana tersebut untuk mengembangkan pos kesehatan, polindes dan posyandu pada tahun 2017.

Selanjutnya nilai rata-rata 3,95 dana desa yaitu bagian dana perimbangan yang diberikan kepada desa dengan tujuan untuk pembangunan desa. Meskipun dalam kategori setuju tetapi banyak masyarakat yang belum mengerti mengenai alokasi dana desa yang diberikan pemerintah pusat kepada pemerintah desa digunakan untuk pembangunan. Begitu juga dengan keefektifan pembangunan fisik desa memperoleh nilai rata-rata 3,95. Pemerintah desa perlu mengembangkan sistem pembangunan di Desa Karang Sari dengan lebih cepat dan tepat sasaran.

\subsubsection{Evaluasi Pembangunan Fisik Desa}

Dari rekapitulasi jawaban responden mengenai tahap pembangunan yaitu dimulai dari perencanaan, pelaksanaan, dan 
pengawasan. Tahap perencanaan mencapai nilai rata-rata 4,14 dan sudah dikatakan efektif. Akan tetapi masih terdapat beberapa jawaban responden berada dibawah rata-rata 4,14 . Jawaban responden yang berada dibawah rata-rata yaitu penyusunan Rencana Pembangunan Jangka menengah dan penetapan skala prioritas program dalam kegiatan perencanaan pembangunan desa dengan nilai rata-rata 4,05. Meskipun dalam kategori efektif, akan tetapi pemerintah desa perlu mengumumkan kepada masyarakat mengenai rencana-rencana pembangunan yang akan datang.

Pada tahap pelaksanaan mencapai nilai rata-rata 3,94 dan dikatakan efektif. Akan tetapi terdapat jawaban responden yang berada dibawah nilai rata-rata yaitu 3,35 dan dikatakan cukup efektif. Hal ini disebabkan karena belum terdapatnya kelompok yang menjaga dan melestarikan hasil pembangunan di Desa Karang Sari Kecamatan Gunung Maligas Kabupaten Simalungun.

Pada tahap pengawasan sudah mencapai nilai diatas rata-rata yaitu 4,25 dan dikategorikan sangat efektif. Meskipun terdapat satu jawaban dibawah rata-rata yaitu 4,20. Akan tetapi pengawasan pemerintah desa sudah dapat dikatakan efektif.

\section{KESIMPULAN DAN SARAN}

\subsection{Kesimpulan}

Adapun kesimpulan dari hasil penelitian yang dilakukan penulis adalah sebagai berikut:

1. Berdasarkan hasil analisis tentang belanja dana desa pada Desa Karang Sari Kecamatan Gunung Maligas Kabupaten Simalungun secara keseluruhan sudah dalam kategori setuju. Nilai tertinggi dari belanja dana desa dalam kategori sangat setuju yaitu pembangunan fisik desa dapat meningkatkan kesejahteraan masyarakat dan nilai terendah dalam kategori setuju yaitu Alokasi Dana Desa digunakan untuk mengembangkan pos kesehatan, polindes dan posyandu.

2. Berdasarkan hasil analisis tentang Pembangunan fisik Desa Karang Sari Kecamatan Gunung Maligas Kabupaten Simalungun pada tahap perencanaan sudah dalam kategori efektif. Nilai tertinggi dari tahap perencanaan dalam kategori sangat efektif yaitu perencanaan pembangunan disusun berdasarkan kesepakatan dan nilai terendah dalam kategori efektif yaitu penyusunan RPJMDes dan penetapan skala prioritas.

3. Berdasarkan hasil analisis deskriptif kualitatif tentang Pembangunan fisik Desa Karang Sari Kecamatan Gunung Maligas Kabupaten Simalungun pada tahap pelaksanaan sudah dalam kategori efektif. Nilai tertinggi dari tahap pelaksanaan dalam kategori efektif yaitu informasi mengenai dokumen RKPDDes dan APBDes, serta nilai terendah dalam kategori cukup efektif yaitu pembentukan kelompok guna menjaga hasil pembangunan.

4. Berdasarkan hasil analisis deskriptif kualitatif tentang Pembangunan fisik Desa Karang Sari Kecamatan Gunung Maligas Kabupaten Simalungun pada tahap pengawasan sudah dalam kategori sangat efektif.

\subsection{Saran}

Dari hasil penelitian, penulis memberikan beberapa saran yang digunakan untuk mengembangkan setiap pembangunan di Desa Karang Sari Kecamatan Gunung Maligas Kabupaten Simalungun dimasa yang akan datang sebagai berikut:

1. Pemerintah desa sebaiknya mengikutsertakan pengembangan pos kesehatan, polindes dan posyandu dalam Alokasi Dana Desa pada tahun yang akan datang.

2. Pemerintah desa sebaiknya melakukan sosialisasi langsung dengan masyarakat setempat secara menyeluruh. Sehingga, masyarakat setempat mengerti dan paham mengenai Alokasi Dana Desa dan hal apa saja yang akan direalisasikan dan sistem pengembangan pembangunan akan menjadi lebih mudah jika semua masyarakat desa mengerti tentang Alokasi Dana Desa.

3. Pemerintah desa sebaiknya memperhatikan kebutuhan-kebutuhan pembangunan yang harus diutamakan secara efektif dan tepat sasaran.

4. Pemerintah desa sebaiknya membentuk kelompok khusus untuk menjaga hasil pembangunan sehingga pengecekan dapat dilakukan secara berkala dan pembangunan dapat terus berjalan secara efektif.

\section{DAFTAR PUSTAKA}

Bastian, Indra. 2006 Akuntansi Sektor Publik. Jakarta: Erlangga

Bastian, Indra. 2015. Akuntansi untuk Kecamatan \& Desa. 2015. Jakarta: Erlangga

Belkaoui, Ahmed Riahi. 2006. Teori Akuntansi. Edisi V, Jilid 1. Jakarta: Salemba Empat.

Riyadi dan Deddy Supriyadi Bratakusumah. 2005. Perencanaan Pembangunan Daerah. Jakarta : PT Gramedia Pustaka Utama

Hafid, Risma. 2016. Pemanfaatan Dana Desa dalam Pembangunan Desa Mangilu Kecamatan Bungoro Kabupaten Pangkep. Makassar: Universitas 
Hasanuddin.

Skripsi.

https://repository.unhas.ac.id. Diakses 2016.

Juliana, Endang. 2017. Efektivitas Pemanfaatan Dana Desa Menunjang Pembangunan Pedesaan di Kabupaten Asahan. Medan: Universitas Sumatera Utara. Skripsi. https://repository.usu.ac.id. Diakses 2017.

Kuncoro, Mudrajad. Dasar-dasar Ekonomika Pembangunan. 2010. Yogyakarta: UPP STIM YKPN Yogyakarta.

Kurnia, Dadang. 2015. Petunjuk Pelaksanaan Bimbingan dan Konsultasi Pengelolaan Keuangan Desa. Jakarta. Diakses April 2015, dari Badan Pengawas Keuangan Pembangunan.

Laonet Payao, Suphawan, Anurak. 2013. Strategies For Capacity Building In Implementing the Village Fund. Amerika: Universitas Sapienza. Jurnal Internasional Vol 4. https://sciencedirect.com. Diakses Maret 2013.

Mardiasmo. Akuntansi Sektor Publik. 2002. Yogyakarta: Andi.

Mauliddin, Arif. 2017. Efektivitas Program Dana Desa di Gampong Meunasah Mee Kecamatan Kembang Tanjong Kabupaten Pidie. Banda aceh: Universitas Islam Negeri Ar-Raniry. Skripsi. https://repository.ar-raniry.ac.id. Diakses 25 Juli 2017.

Mulyani, Sri. 2017. Buku Saku Dana Desa. Jakarta: Kementerian Keuangan Republik Indonesia. Diakses tanggal 04 Desember 2017, dari Kementerian Keuangan Republik Indonesia.

Siswati, Murni. 2012. Efektivitas Penggunaan Alokasi Dana Desa (ADD) dalam Pembangunan Desa di Desa Padang Luas Kecamatan Tambang Kabupaten Kampar. Riau: Universitas Islam Negeri Sultan Syarif Kasim. Skripsi. https://repsitory.uin.suska.ac.id. Diakses 24 November 2016.

Mursyidi. 2002. Akuntansi Dasar. Jilid 1. Bogor: Ghalia Indonesia.

Nordiawan, Iswahyudi dan Maulidah. Akuntansi Pemerintahan. 2008. Jakarta: Salemba Empat.

Prabawa, Akbar. 2015. Pengelolaan Alokasi Dana Desa dalam Pembangunan di Desa Loa Lepu Kabupaten Kutai Kertanegara. Samarinda: Universitas Mulawarman. Jurnal Akuntansi. https://ejournal.ip.fisip.unmal.ac.id. Diakses tanggal 25 Februari 2015.

Purwanti dan Indah Nugraheni. 2001. Siklus Akuntansi. Yogyakarta: Kanisius.

Renyowijoyo, Muindro. Akuntansi Sektor Publik. 2008. Jakarta: Mirta Wacana Media.
Republik Indonesia. 2014. Undang-Undang Nomor 6 Tahun 2014 Tentang Desa.

Republik Indonesia. 2014. Peraturan Pemerintah Dalam Negeri Nomor 114 Tahun 2014 Tentang Pembangunan Desa.

Republik Indonesia. Peraturan Pemerintah Nomer 47 Tahun 2015 Tentang Desa.

Republik Indonesia. 2015. Peraturan Menteri Desa Nomor 5 Tahun 2015 Tentang Penetapan Prioritas Penggunaan Dana Desa.

Rudianto. 2009. Pengantar Akuntansi. Jakarta: Erlangga.

Santosa, Pandji. 2008. Administrasi Publik. Bandung: Refika Aditama

Sugiyono. 2013. Metode Penelitian Kuantitatif dan Kualitatif R\&D. Bandung: Alfabeta

Sulastri, Nova. 2016. Efektivitas Pengelolaan Alokasi Dana Desa (ADD) dalam Meningkatkan Pembangunan Fisik Desa Lakapodo Kecamatan Watapue Kabupaten Muna. Kendari: Universitas Halu Oleo. Skripsi. https://sitedi.uho.ac.id. Diakses Juli 2016.

Widjaja, HAW. Otonomi Desa. 2005. Jakarta: Raja Grafindo Persada. 